\title{
Analysing Seasonal Changes in New Zealand's Largest Inbound Market
}

\author{
CHRISTINE LIM and MICHAEL MCALEER
}

\begin{abstract}
The purpose of the paper is to analyse seasonal changes in tourism demand by New Zealand's major tourist source market, Australia, for the period 1979-2005. A time series regression model is used to test the significance of monthly seasonality. By examining sub-periods that are based on major exogenous events which have had significant impacts on international travel demand to New Zealand, seasonal distributions and intra-year seasonal variations over the 27 year period are subsequently estimated using normalized seasonal indices, coefficient of variation, seasonal ratio and the Gini coefficient. Compared with the findings of previous studies for other countries, the empirical evidence suggests that, while the tourism flow distribution or concentration is not significant for New Zealand, the seasonality in tourism demand by New Zealand's largest inbound market has changed over time.

Keywords: international travel demand; exogenous events; monthly seasonality; tourism flow distributions.
\end{abstract}

\section{Introduction}

Tourism has played a critical and expanding role in New Zealand's economy. With the slump in agricultural export earnings in 1967 and economic depression in many rural regions in the mid-1980s as a result of the reduction and/or removal of farm subsidies, the contributions of international tourism have been viewed as cruciäl to New Zealand's economic recovery and diversification. While the filming of The Lord of the Rings has undoubtedly raised the tourism profile of New Zealand internationally, its spectacular landscapes and natural environment are arguably its major drawcard in inbound tourism. Tourism New Zealand's 100\% Pure campaign on the portrayal of a clean green destination image and $100 \%$ pure quality experience, has certainly been very successful. Of late, New Zealand's Maori cultural heritage and Maori-led tourism are the second biggest attractions for international tourists. An excellent example of this enterprise is the Whale Watch in Kaikoura.

The primary purpose of this paper is to examine and estimate tourism demand seasonality for New Zealand by its major, and largest short-haul, tourist generating market, Australia, for the period 1979 to 2005. Short term tourist arrivals to New Zealand have displayed strong seasonal patterns, and the seasonality phenomenon has become more pronounced since the mid-1990s. In particular, this paper will examine intra-year seasonality and evaluate seasonality with respect to the distribution of tourist flows from Australia during the 27-year period.

The remainder of the paper has been organized in five parts. An overview of tourism development in New Zealand and some background information on Australian tourists are given in first part. Second part briefly discusses some key concepts and the theoretical framework of time series regression. The methodological approach that is used for measuring intra-year seasonality and tourism flow distributions is examined in third and fourth part respectively. Additionally, the findings in part four will be compared with other studies on some European destinations. Some concluding remarks are given in the last part.

Monthly data on tourist arrivals from Australia to New Zealand for January 1979 to December 2005 were obtained from New Zealand Department of Statistics (1979-2005). The EViews 5.1 econometric software package was used to generate the empirical results.

\section{Overview of Tourism Development in New Zealand}

New Zealand, formerly known as Aotearoa, was first inhabited by the Maori. It would seem that New Zealand was the first country in the world to establish a national tourism organization. In 1901 the Department of Tourist and

CHRISTINE LIM is Professor of Tourism Management at the Department of Tourism and Hospitality Management, University of Waikato, Private Bag 3105, Hamilton, New Zealand. e-mail: clim@waikato.ac.nz

MICHAEL MCALEER is Professor of Economics at the University of Western Australia and Adjunct Professor at Universities in New Zealand, Spain, Thailand and Taiwan. e-mailanichaelancaleer@gmail.com 
Health Resorts was established to promote the country as a pleasure-seeking destination. The New Zealand government has had a long history of being pro-active in the tourism industry until the 1980s and 1990s. The national airline, Air New Zealand, purchased a 50\% share of the Australian-based Ansett Airlines in 1995 to gain greater access to its Asian routes. However, the government had to 'rescue' Air New Zealand in 2001 by becoming a majority shareholder through acquiring an $80 \%$ share in the airline. This occurred as a result of the collapse of Ansett Airlines and the downturn in global travel after the 11 September 2001 terrorist attacks in the USA. Hence, the role of the government has evolved from one of dominating the industry to a supportive role in partnership with the private sector and community stakeholders.

Overseas arrivals to New Zealand accelerated since 1984, which coincided with the country's economic and political restructuring that was initiated by the Fourth Labour Government in the same year. In particular, the floating and subsequent depreciation of the New Zealand dollar was instrumental in the growth of international tourist arrivals (Lim et al. 2003). Australia is New Zealand's largest tourist market, so that New Zealand's tourism is arguably highly dependent on arrivals from Australia. Much of New Zealand's growth in tourism numbers in the early 1970s was from Australia, when discretionary income was rising under the Whitlam Labor Government. In 1983, Australia contributed about $45 \%$ of New Zealand's overseas arrivals, but the market composition has decreased and stabilized to about $37 \%$ in 2005 . Despite some changes in the intervening years, one-third of overseas arrivals to New Zealand was from Australia during the period 1996 to 2005 .

The New Zealand Government increased funding in its 2006 budget for Tourism New Zealand, the Governmentfunded marketing organization, to promote the country overseas. In particular, Tourism New Zealand is keen to showcase the country in Australia through food and wine festivals in Sydney and Melbourne. A special marketing campaign has also been launched in Southern Queensland, which is New Zealand's second largest tourist source market in Australia (Bennett 2006; DaCruz 2006; Hembry 2006).

There has clearly been an upward trend in tourist arrivals from Australia since the late 1970s. In terms of trip purposes, holiday or vacation is the main reason given by Australian tourists for visiting New Zealand (Figure 1). However, Australians are as likely to travel for purposes of visiting friends and relatives (VFR) since the 1990s. VFR travel has increased continuously since the late 1980s, and has become as important as holiday travel in the Australian outbound market to New Zealand.

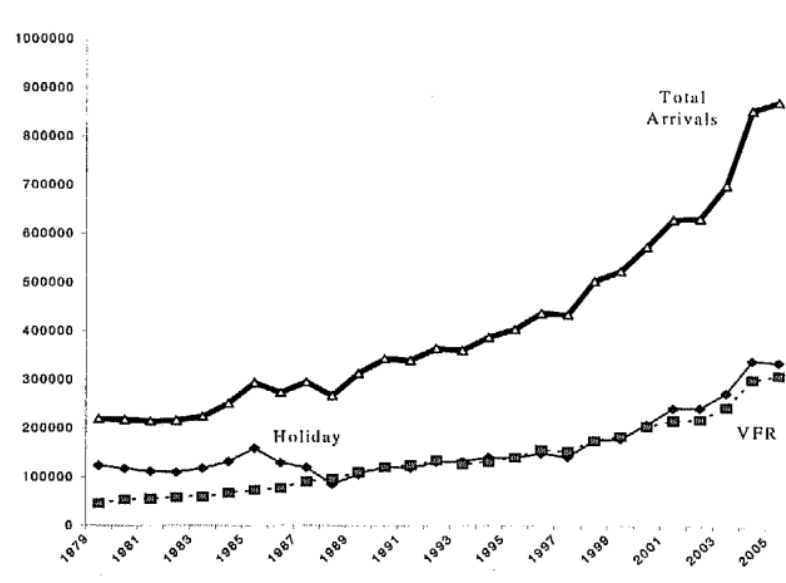

Figure 1. Tourist Arrivals from Australia by Purpose of Trip, 1979-2005

When Oppermann (1994) compared the length of stay for all tourists to New Zealand in 1983 and 1991, the trend towards a shorter length of stay was observed. When we consider the same for tourist arrivals from Australia in 199 and 2005 (Table 1), the change in proportion has become more pronounced for this market. The two categories that stand out for the Australian tourists are the increase in the 1-3 days duration and the decrease in the 1-2 months length of stay. In 2005, the largest proportion of Australians came to New Zealand for 2-4 weeks.

Table 1. Proportion of Length of Stay by Australian Tourists in 1996 and 2005

\begin{tabular}{|c|c|c|}
\hline Length of Stay & $\mathbf{1 9 9 6}$ & $\mathbf{2 0 0 5}$ \\
\hline 1-3 days & 0.05 & 0.12 \\
\hline 4-6 days & 0.10 & 0.13 \\
\hline 7-10 days & 0.18 & 0.20 \\
\hline 11-14 days & 0.15 & 0.13 \\
\hline 2-4 weeks & 0.28 & 0.25 \\
\hline 1-2 months & 0.16 & 0.10 \\
\hline 2-3 months & 0.04 & 0.03 \\
\hline 3-12 months & 0.04 & 0.04 \\
\hline
\end{tabular}

While visitor numbers and foreign exchange earnings from tourism have been rising, tourism development has also made a significant impact on regional economic development in New Zealand. One of the many issues in the development of tourism confronting New Zealand, as discussed in Hamilton (1988), Oppermann (1994) and Pearce (1990), is related to regional destination imbalances and disparities in tourism growth. According to their studies on spatial distributions and concentrations, it is not surprising that Auckland and Christchurch (in Canterbury province), which are the major international gateways to New Zealand, have 
benefited the most as the major national tourist destinations in terms of tourist arrivals and expenditures. However, the dimension of seasonality and tourism flow distributions in New Zealand over time have not been addressed in these studies.

Seasonality in tourism is a reality that has been faced by almost all destinations, 'varying only in the degree of its acuteness from one country to another' (Yacoumis 1980: 84)). The causes and/or problems associated with seasonality that have been discussed in the tourism research literature are often linked to economic impacts. They are primarily associated with short-term employment and revenue generation due to the short operating period of tourism businesses, difficulty in recruiting and retaining full-time staff, the consequent under-utilization and / or inefficient use of tourism capital, business uncertainty and related supplyside problems (see, for example, Butler and Mao 1997; Baum and Lundtorp 2001; Butler 2001; Fernandez-Morales 2003). It is important to understand the phenomenon of seasonality and to examine origin-market-specific seasonality in order to promote New Zealand strategically in the origin country (such as Australia).

\section{Key Concepts and Theoretical Framework}

According to Hanke et al. (2001), 'a time series consists of data that are collected, recorded, or observed over successive increments of time' (p. 54). Tourism time series that are observed at quarterly and monthly frequencies, such as tourist arrivals, can be deconstructed into four components, namely secular trends, cyclical movements, and seasonal and irregular components. Long term upward and/ or downward movements in international tourist arrivals comprise the trend component, which is often characterized as being linear. The former occurs, among other reasons, because of changes in population and income, technological progress, and shifts in consumer tastes for international travel by various groups in the population. The cyclical component is the wave-like movement around trend. It can be quite difficult to distinguish between the trend and cyclical components in tourism series, especially in the short term. For this reason, it is assumed that the trend includes the cyclical component, and this combination is also known as the trend-cycle, or simply the trend component.

Another salient feature of a tourism time series is seasonal variation, which tends to be repeated on an annual basis. International tourism demand may also be seriously affected by irregular fluctuations which are random, resulting from unusual or unanticipated events, such as currency crises, devaluations, wars, unseasonable weather, and healthrelated factors in the origin and/or destination countries.
We assume a linear model in the variables in which the data on $\mathrm{y}_{1}, \ldots, \mathrm{y}_{\mathrm{t}}$ are generated by $\mathrm{y}_{\mathrm{t}}=a+\beta x+\varepsilon_{t}$, such that $\mathrm{y}_{\mathrm{t}}$ depends linearly on $\mathrm{x}_{\mathrm{t}}$. Other assumptions of the classical linear regression model include the following:

(1) Expected value of the disturbance term is zero: $\mathrm{E}\left(\mathrm{E}_{\mathrm{t}}\right)=$ 0

(2) Homoskedasticity, or constant variance of the disturbances: $\operatorname{Var}\left(\varepsilon_{\mathrm{t}}\right)=\sigma_{\mathrm{e}}^{2}$ for all $\mathrm{t}$;

(3) No serial correlation of the disturbances across time periods: $E\left(\varepsilon_{t} \varepsilon_{s}\right)=0(\mathrm{t} \neq \mathrm{s})$;

(4) Explanatory variables are weakly exogenous, that is, there is zero covariance between $\varepsilon_{t}$ and each explanatory variable: $\mathrm{E}\left(\mathrm{x}_{\mathrm{t}} \varepsilon_{t}\right)=0$ for all $\mathrm{t}$;

( 5 ) $\varepsilon_{t}$ are normally distributed: $\varepsilon_{t} \sim \mathrm{N}\left(0, \sigma_{e}{ }^{2}\right.$,) for all t;

(6) Parameter constancy: $\alpha, \beta$ and a are unknown constants, with $\sigma>0$.

The focus in this paper is on the time series models of a single variable, as we pay special attention to the analysis of monthly seasonal patterns and distributions of tourist arrivals that are observed sequentially over time. It can be more informative to use monthly seasonally unadjusted series to construct the seasonal component and to derive the seasonal indices so as to examine the seasonal behaviour of tourism demand. If quarterly observations were used, it would be difficult to determine whether tourist arrivals for each month in any quarter had the same seasonal effects. In some quarters, we could have a mix of high and low seasonal monthly arrivals.

Before we analyse the monthly seasonal behaviour of tourist demand, it is useful to examine the overall contributions and significance of seasonality to the growth in tourist arrivals. Seasonal dummy variables are often used in time series regressions to capture deterministic monthly seasonal effects on tourism demand. The tourist arrival time series show a trending pattern (Figure 1). In such cases, the statistical assumptions may hold by taking the logarithmic transformation of the series, and first differences (as denoted by $A$ ) in order to remove the trend. By regressing the first difference of the logarithm of tourist arrivals on seasonal dummy variables, we transform the original series into growth rates.

The regression model to be estimated is:

$$
\Delta \log y_{t}=\sum_{\mathrm{s}=1}^{12} \delta_{s} D_{s t}=\delta_{1} D_{1 t}+\delta_{2} D_{2 t}+\cdots+\delta_{12} D_{12}+\varepsilon_{t}
$$


where

$\mathrm{y}_{\mathrm{t}}=$ monthly tourist arrivals at time $\mathrm{t}$;

$D_{s t}=$ dummy variable for seasons;

$\delta_{s}=$ coefficient of the seasonal dummy variable, which measures tourist arrivals in season s;

$e_{t}=$ independently and identically distributed stationary error term.

The dummy variable for season $\mathrm{s}$ is equal to 1 for observations in that season and 0 otherwise, and $\mathrm{O}_{\mathrm{s}}$ is a coefficient of the seasonal dummy, which measures the monthly growth rate of tourist arrivals in season s. As monthly time series data are used, the total number of seasons is equal to 12 . Using the ordinary least squares estimation method, the empirical results obtained are significant for eight out of twelve seasons (or months). Since the R-squared value indicates the amount of deterministic seasonality that is present in the tourist arrival series, it can be interpreted that the seasonal dummies account for $78 \%$ of the variation in the growth in tourist arrivals from Australia.

Analysis of Intra-year Seasonality

A useful way of examining the seasonal patterns of tourist arrivals from Australia is to estimate the average monthly seasonal indices using the multiplicative ratio-tomoving average technique as follows:

$$
\mathrm{MA}_{\mathrm{t}}=\left[\mathrm{A}_{\mathrm{t}+6}+2 \sum_{\mathrm{x}=1}^{11}\left(\mathrm{~A}_{\mathrm{t}+6-\mathrm{x}}\right)+\mathrm{A}_{\mathrm{t}-6}\right] / 24
$$

where $\mathrm{MA}_{\mathrm{t}}$ is the centred moving average of tourist arrivals for month $t$ and $A_{t}$ is the number of tourist arrivals in month $\mathrm{t}$ (see Lim and McAleer 2001, for details). The technique is computationally convenient as it involves straightforward calculations, which looks forward and backward in time. Note that the multiplicative model should only be used if the series are always positive.

The computational procedure used, separates the seasonal and irregular components from the trend component by computing the average of the first 12 observations. This will yield the average monthly tourist arrivals for year 1 of the time series. Continuing the moving average calculation requires us to add the first month tourist arrivals of year 2 (the $13^{\text {ill }}$ observation of the time series) and omit the same in year 1 (the $1^{\text {st }}$ observation). Similarly, the third moving average is calculated by including the second month tourist arrivals of year $2\left(14^{\text {th }}\right.$ observation $)$ and deleting the same of year 1 ( $2^{\text {nd }}$ observation). We proceed with the moving average calculations for the entire time series, which yields the twelve-month moving average series. Note that the moving average value in the latter represents the mean of an even number of data points, that is, they would lie between two data points. They would be correctly centred if we take a double moving average, giving rise to the centred moving average series.

As in the case of the multiplicative model, in which the original series $(\mathrm{Y})$ is the product of the trend $(\mathrm{T})$, seasonal $(\mathrm{S})$ and irregular (I) components: $\mathrm{Y}=\mathrm{T} * \mathrm{~S} * \mathrm{I}$, we have used the moving averages to estimate $\mathrm{T}$ (that is, $\mathrm{MA}=\mathrm{T}$ or $\mathrm{Y} / \mathrm{MA}=\mathrm{S}$

* I). A further averaging process will then remove I, leaving $\mathrm{S}$, as required. Thus, the seasonal indices are derived by dividing the original series by the MA series. If the sum of the average monthly indices is not equal to 1200 (wherein the average monthly index is 100), the average monthly indices are subsequently normalized by making an appropriate proportional adjustment. Since the unadjusted indices add up to 1226.1 , each of the monthly value is multiplied by $1200 / 1226.1$, and expressed to the nearest whole number.

Tourism months, or high seasons, are defined as months for which the corresponding average indices exceed 100. Table 2 shows that September (as well as December through to March) was a high season for Australian tourists during the period 1979 to 2005 (see column 2). In the peak month of December, we could expect tourist arrivals to be about $70 \%$ above the annual average, and $24 \%$ below the annual average in the lowest month of May.

Table 2. Monthly Seasonal Indices for Tourist Arrivals from Australia, 1979-2005

\begin{tabular}{|l|c|c|c|c|}
\hline Month & $\begin{array}{c}\text { Full } \\
\text { Sample } \\
\mathbf{1 9 7 9 ( 1 ) -} \\
\mathbf{2 0 0 5 ( 1 2 )}\end{array}$ & $\begin{array}{c}\text { Sub- } \\
\text { sample 1 } \\
\mathbf{1 9 7 9 ( 1 ) -} \\
\mathbf{1 9 8 7}(\mathbf{9})\end{array}$ & $\begin{array}{c}\text { Sub- } \\
\text { sample 2 } \\
\mathbf{1 9 8 7 ( 1 0 ) -} \\
\mathbf{1 9 9 7 ( 9 )}\end{array}$ & $\begin{array}{c}\text { Sub- } \\
\text { sample 3 } \\
\mathbf{1 9 9 7 ( 1 0 ) -} \\
\mathbf{2 0 0 5 ( 1 2 )}\end{array}$ \\
\hline January & 103 & 108 & 101 & 100 \\
\hline February & 100 & 99 & 99 & 101 \\
\hline March & 110 & 109 & 111 & 110 \\
\hline April & 97 & 92 & 95 & 106 \\
\hline May & 76 & 84 & 70 & 74 \\
\hline June & 80 & 79 & 83 & 77 \\
\hline July & 89 & 80 & 93 & 95 \\
\hline August & 93 & 101 & 89 & 92 \\
\hline September & 103 & 84 & 113 & 108 \\
\hline October & 88 & 82 & 89 & 91 \\
\hline November & 91 & 85 & 93 & 94 \\
\hline December & 170 & 197 & 164 & 152 \\
\hline
\end{tabular}

Bar-On's (1999: 437) definition of seasonality as 'the effects occurring each year with more or less the same timing and magnitude' may be true in the short run. Over time, there have been changes in the intra-year seasonal patterns 
of tourist flows from Australia to New Zealand due to major exogenous factors, such as the 1987 October stock market Crash and the 1997 Asian economic and financial crises. In addition to the full sample period, the average monthly seasonal indices for the sub-sample periods comprising 1979(1)4987(9), 1987(10)-1997(9) and 1997(10)-2005(8) for Australia are computed. Given Australia's trade ties with Asia and the discretionary nature of international travel demand, the 1997 financial and economic crises have adversely affected Australia's economy and travel affordability.

The rest of Table 2 provides some interesting results for tourist arrivals from Australia to New Zealand when the full and sub-sample results are compared. The latter indicates that the seasonal patterns have not been consistent during the full sample period. Over time, New Zealand has been receiving more tourists from Australia in April and September, and fewer tourists in August. While December still remains the most popular month for Australian tourists, the influence of the peak season has declined noticeably, as shown by the three sub-sample indices. A likely contributing factor could be changes in the school holiday patterns in Australia, which Butler (2001) described as an institutionalized push factor in travel demand.

As discussed above, the intra-year variations of tourist arrivals and their changes over time could be related to institutional factors at the origin countries and/or major economic /financial events. Additionally, trans-Tasman developments (in migration, trade, air transportation, among others) could have some impact on inbound travel from Australia over time. The unimpeded movement of citizens across the Tasman Sea (without any visa requirements) accounts for one-half of the total arrivals and departures in New Zealand annually. The strong historical, social cultural-sporting and economic ties between the two countries have been strengthened by the Closer Economic Relations (CER) agreement, which has gradually allowed the free movement of goods, capital and services between the two countries.

With more than $10 \%$ of New Zealanders living in Australia (namely, more than 450,000 individuals), it is not surprising that trans-Tasman migration is a major contributing factor to the VFR travel from Australia to New Zealand (Bedford et al. 2000, 2003). For decades, air travel between the two countries has been dominated by the traditional national carriers, namely Air New Zealand and Qantas. The entry and expansion of budget and no-frills airlines (either as stand alone low-cost carriers or low-cost subsidiaries of traditional airlines), such as Kiwi International, Freedom Air, Jetstar, Virgin Blue and Origin Pacific, have made airfares on the trans-Tasman air routes more competitive. Some of these airlines have gone bankrupt due to intense oligopolistic competition and behaviour on the trans-Tasman air route (Haugh and Hazledine 1999).
Yacoumis (1980) used two measures to determine seasonal fluctuations of tourist arrivals during the year, namely the coefficient of (seasonal) variation and the seasonal ratio. If the seasonal indices are used to compute the coefficient of seasonal variation (CSV), the CSV is equal to the standard deviation of the seasonal indices as the average normalized index is equal to 1.0. Alternatively, the coefficient of variation $(\mathrm{CV})$ can be defined as the standard deviation of tourist arrivals from a particular source market divided by their mean. The CSV and CV for the Australian tourist market are 0.24 and 0.52 , respectively.

The seasonal ratio for New Zealand's single largest tourist market over the 27-year period is estimated, based on Yacoumis' (1980) definition, as the ratio between the highest number of monthly arrivals in any one year and the average number of tourists per month during the year. As the seasonality ratio demonstrates the influence of the peak month, the higher (lower) the ratio, the greater (smaller) is the seasonal variation. The seasonality ratio for tourist arrivals from Australia varies between 1.42 and 2.09. It is worth noting that the seasonal ratio for the Australian market has declined over time, indicating that seasonal fluctuations have decreased from 1979 to 2005 (see Figure 2). For purpose of comparison, Bar-On (1999) has estimated the seasonal ratio between the peak and trough months for hotel occupancy. On the basis of a cross-sectional study of 16 countries, the estimated seasonal ratio in Bar-On (1999) ranges from 1.21 to 15.24 in 1998 .

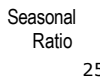

25 ,

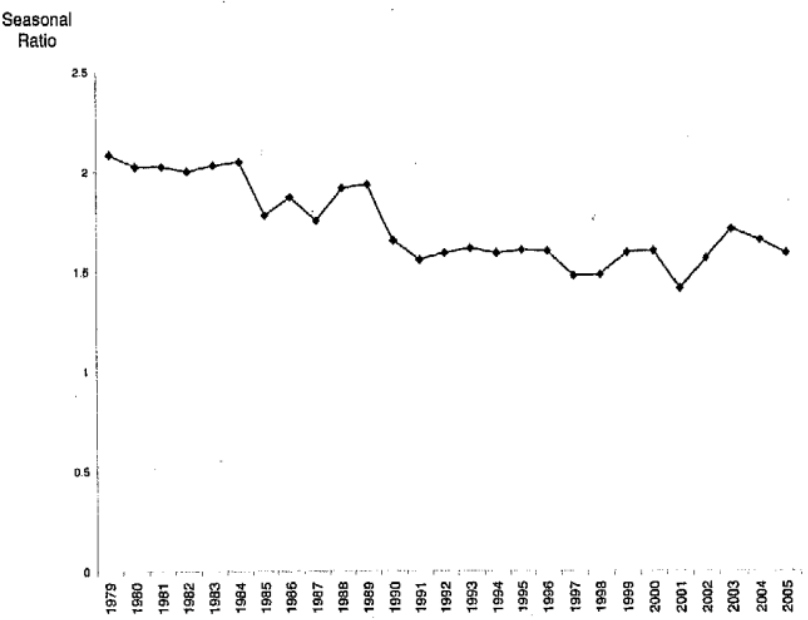

Figure 2. Seasonal Ratio for Tourist Arrivals from Australia, 1979-2005 


\section{Estimating Seasonal Distributions of Tourist Arrivals}

Seasonality is often associated with seasonal demand patterns and it is important to determine how tourism demand is distributed over the years. Using measures such as the coefficient of (seasonal) variation and the seasonal ratio, have been criticized as deficient as they do not take into account the skewness of the distribution of the variable of interest (or tourist arrivals, in this case). For this reason, Wanhill (1980), Lundtorp (2001) and Nadal et al. (2004) recommended the estimation and use of the Gini coefficient.

The Gini coefficient and the Lorenz curve, which are well known tools for measuring income distribution or inequality (Campano and Salvatore 2006) can be used to provide evidence on tourist arrival distribution. While the Lorenz curve is a graphical representation of the degree of inequality of the tourist arrival distribution from a particular market in any one year, the Gini coefficient provides a measurable index of inequality. The studies by Lundtorp (2001), Fernandez-Morales (2003) and Nadal et al. (2004) have all computed the Gini values for their selected destinations. However, only Lundtorp (2001) has provided the Lorenz curve in conjunction with the Gini estimates. In addition to using both measures, the procedures involved in the computation of the Gini coefficients will be discussed briefly as this has been lacking in previous studies.

The monthly tourist arrivals are ranked from the lowest to the highest frequency to obtain the Lorenz curve. Specifically, the Lorenz curve shows the relationship between the cumulative relative frequency (of arrivals) from the lowest to the highest month (y-axis) and their cumulative month ( $\mathrm{x}$ axis). The diagonal line (or line of equality) represents the tourist arrival distribution, whereby all months have exactly the same number of arrivals. The tractile distribution of tourist arrivals produces the Lorenz curve for a particular year. In the extreme case where all the tourist arrivals are concentrated in one month of the year (and other months have zero tourist), the Lorenz curve would be represented by the horizontal axis and the vertical axis on the right side of the figure. Thus, the area between the Lorenz curve of a tourist market and the line of equality represents the unequal seasonal distribution of tourist arrivals from that market. The larger the area, the greater is the unequal distribution of tourist arrivals. The Lorenz curve for the Australian market in 2005 is represented by the broken line in Figure 3.

The area between the diagonal and the Lorenz curves is known as the concentration area. Thus, the Gini coefficient can be expressed as the ratio of the concentration area to the area of the triangle below the diagonal line. If New Zealand were to have an equal number of tourists from Australia

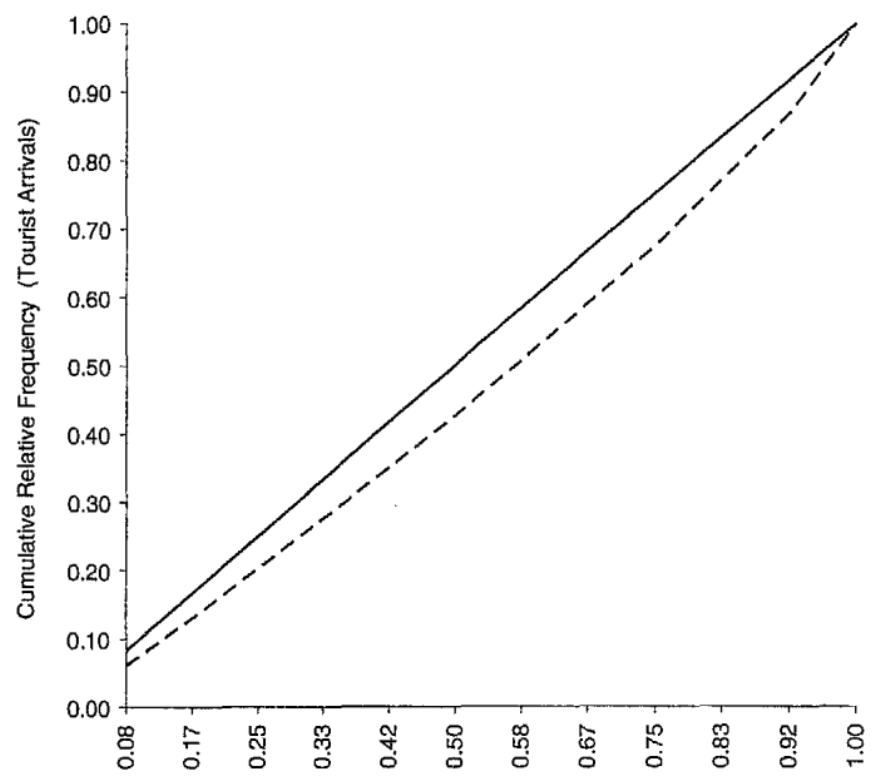

Figure 3. Lorenz Curve for Tourist Arrivals from Australia, 2005

each month, the Lorenz curve would coincide with the diagonal line, and the Gini coefficient would be zero. In the extreme case where all the arrivals are concentrated in one month, the Gini coefficient would be 11/12. Theoretically, the Gini coefficient lies between 0 and 1 . The closer is the ratio to 0 , the more equally distributed will be the tourist flows from that market (or the lower will be the degree of seasonal concentration).

Before estimating the Gini coefficient, the monthly tourist arrivals in any one year must be ranked in ascending order and then the cumulative relative frequency for tourist arrivals is computed. The Gini coefficient of a particular market can be calculated for any one year as follows:

$\mathrm{G}=2 / \mathrm{n} \sum_{\mathrm{i}=1}^{\mathrm{n}}\left(\mathrm{x}_{\mathrm{i}}-\mathrm{y}_{\mathrm{i}}\right)=2 / \mathrm{n}\left[\left(\mathrm{x}_{1}-\mathrm{y}_{1}\right)+\left(\mathrm{x}_{2}-\mathrm{y}_{2}\right)+\ldots+\left(\mathrm{x}_{\mathrm{n}}-\mathrm{y}_{\mathrm{n}}\right)\right]=2 / \mathrm{n}\left[\sum_{\mathrm{i}=1}^{\mathrm{n}} \mathrm{x}_{\mathrm{i}}-\sum_{\mathrm{i}=1}^{\mathrm{n}} \mathrm{y}_{\mathrm{i}}\right]$

where

$\mathrm{n}=$ number of fractiles (that is, 12 for monthly arrivals);

$x_{i}=$ rank of the fractiles $(1 / 12,2 / 12,3 / 12, \ldots, 12 / 12)$;

$y_{i}=$ cumulative relative frequency of tourist arrivals in rank by ascending order.

Using tourist arrivals from Australia in 2005, the computation of the Gird coefficient is shown below: 


\begin{tabular}{|r|c|c|}
\hline \multicolumn{1}{|c|}{$\mathrm{x}_{\mathrm{i}}$} & $\begin{array}{c}\text { Frequency } \\
\text { (tourist arrivals) }\end{array}$ & $\begin{array}{c}\text { yi (cumulative } \\
\text { relative frequency } \\
\text { in rank) }\end{array}$ \\
\hline $1 / 12=0.08$ & 53124 & 0.061 \\
\hline $2 / 12=0.17$ & 60648 & 0.130 \\
\hline $3 / 12=0.25$ & 63526 & 0.203 \\
\hline $4 / 12=0.33$ & 64078 & 0.276 \\
\hline $5 / 12=0.42$ & 64260 & 0.349 \\
\hline $6 / 12=0.50$ & 66960 & 0.426 \\
\hline $7 / 12=0.58$ & 70056 & 0.506 \\
\hline $8 / 12=0.67$ & 72490 & 0.589 \\
\hline $9 / 12=0.75$ & 74269 & 0.674 \\
\hline $10 / 12=0.83$ & 83952 & 0.770 \\
\hline $11 / 12=0.92$ & 85125 & 0.867 \\
\hline $12 / 12=1.00$ & 116250 & 1.000 \\
\hline Total & 874738 & 5.851 \\
\hline
\end{tabular}

Note that the lower frequencies (namely, the second column) above do not necessarily coincide with the colder months, and the higher frequencies with warmer months in New Zealand. Based on the above computation, the estimated Gini ratios for tourist arrivals from Australia from 1979 to 2005 are given in Figure 4. Over the years, the Gird coefficient for the Australian market has assumed varying levels of intensity. If we use the same sub-sample periods (as discussed earlier), Figure 4 shows that the Gini coefficients for the Australian market have decreased. The Gini ratios are invariably higher in the 1979-1987 sub-sample and lower in the 1997-2005 sub-sample. From 1979 to 1987, the Gini estimates ranged from 0.11 to 0.20 , from 0.09 to 0.14 in 19881997 , and from a low of 0.09 to a high of 0.11 in 1997-2005. Hence, the annual seasonal concentration or distribution of tourist flows from Australia has declined over time.

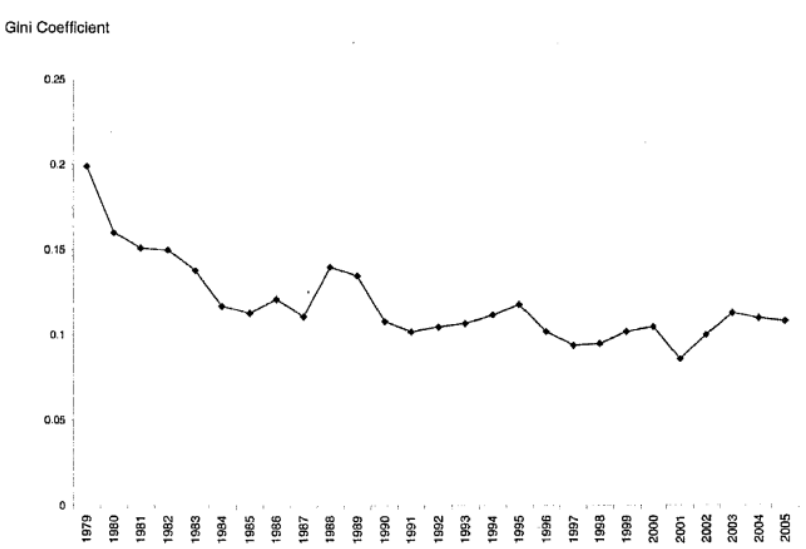

Figure 4. Gini Coefficient for Tourist Arrivals from Australia, 1979-2005
Fernandez-Morales (2003), Lundtorp (2001) and Nadal et al. (2004), the Gini coefficient has been computed for some destinations in Denmark and Spain. The sample sizes used by Fernandez-Morales (2003) and Nadal et al. (2004) are larger than previous studies (specifically, 22 years and 20 years of monthly tourist arrivals time series data, respectively), and are comparable to the current study (a summary of their Gini findings is given in the table below). Almeria, Granada and Malaga in the province of Andalusia are the three Spanish Mediterranean destinations under study in Fernandez-Morales (2003). While the study only disclosed the minimum and maximum Gini coefficients for Andalusia (that is, between 0.16 and 0.22 ), the minimum value for Granada was found to be as low as 0.09 .

The Gini estimates obtained by Lundtorp (2001) are wide ranging, with higher minimum/maximum ratios for the summer regions, while the regions near the capital (Copenhagen) area tend to experience lower seasonal fluctuations. The study by Nadal et al. (2004) has more in common with the present study because it computes the Gini coefficient for two international markets (namely, British and German tourist arrivals) to the Balearic Islands in Spain, with both being short-haul markets. If we compare their estimated Gini coefficients with New Zealand's largest short-haul market, Australian tourist arrivals have 'outperformed' the dominant markets for the Balearic Islands.

\begin{tabular}{|l|l|l|}
\hline Author(s) & Destination(s) & Gini estimate range \\
\hline Lundtorp (2001) & $\begin{array}{l}\text { Sixteen } \\
\text { regions/counties in } \\
\text { Denmark }\end{array}$ & $\begin{array}{l}\text { O.09-0.13 (West } \\
\text { Zealand) 0.48 - 0.55 } \\
\text { (Bornholm) }\end{array}$ \\
\hline $\begin{array}{l}\text { Fernandez-Morales } \\
\text { (2003) }\end{array}$ & $\begin{array}{l}\text { Andalusia (Spain) } \\
0.16-0.22\end{array}$ \\
\hline Nadal et a/.(2004) & $\begin{array}{l}\text { Balearic Islands } \\
\text { (Spain) }\end{array}$ & $\begin{array}{l}0.26-0.33 \text { (German } \\
\text { market) } \\
0.32-0.37 \text { (British } \\
\text { market) }\end{array}$ \\
\hline $\begin{array}{l}\text { This paper (Lim and } \\
\text { McAleer 2008) }\end{array}$ & New Zealand & $\begin{array}{l}\text { No9-0.20 (Australian } \\
\text { market) }\end{array}$ \\
\hline
\end{tabular}

\section{Conclusion}

For a country which has lost its competitiveness in several key industries, and has seen its productivity eroded through institutional rigidities in the 1970s and 1980s, Australia has achieved one of the highest growth rates in the OECD economies over the last decade (with the exception of Ireland and Luxembourg). Political, social, and particularly, economic reforms have lifted the country to a new trajectory of economic growth (Bloch 1996; Fare et al. 2001). Given New Zealand's close proximity to Australia 
and their special historical ties, New Zealand will continue to benefit as it taps into the trans-Tasman tourism growth opportunities emanating from Australia.

The purpose of this paper was to examine the intertemporal development of seasonal demand for international travel by the major short-haul market of New Zealand from 1979 to 2005. Various measures have been used to analyse seasonality, with the time series regression model having shown that monthly seasonality was significant. Furthermore, this paper has provided a useful approach to examine this phenomenon, namely by compartmentalizing the full sample into sub-samples or sub-periods of tourist arrivals. The latter is based on major exogenous economic/financial and political events which have had significant impacts on international travel demand.

The empirical findings of this paper have shown that seasonality in terms of intra-year monthly variations in tourist arrivals have not remained constant for the Australian market during the 27-year period. Additional insights into the changes of intra-year seasonal demand of these inbound markets have been obtained from the subperiods. The normalized monthly seasonal indices indicated that some of the months which were formerly tourism seasons (such as August) are no longer the case. The empirical analysis showed evidence that monthly seasonality in tourism demand has changed over time.

This paper has also estimated alternative seasonal indicators for a comparative analysis, including the coefficient of seasonal variation, seasonal ratio and Gini coefficient. The seasonal ratio and Gini coefficient estimates indicated that the seasonal concentration for the Australian market has declined over time. Although the magnitude of tourism demand varies from country to country or destination to destination, these measures which are unit-independent, allow a comparison of the seasonality performance across countries or destinations. In comparison to the findings in previous studies, the empirical evidence from this paper suggests that tourism flow distributions from Australia are less of a problem for New Zealand.

Just as social policy-makers are interested in income distribution, tourism destination policy-makers should be concerned about tourism demand patterns and seasonal distributions, in general, and of the major tourist markets, in particular. Besides increasing marketing expenditures to attract more tourists from Australia, it is important for
Tourism New Zealand to build a more sustainable tourism demand from this market. The latter requires a better understanding of seasonality to make informed marketing decisions, and to optimize the returns on significant marketing expenditures. Should the marketing efforts be capacity/managed volume or strategic driven? If the former leads to an expansion of (and heightens) the tourism seasons, it will only intensify the seasonal concentrations of tourists in New Zealand. However, if the emphasis is more than just simply increasing tourist numbers from these tourism source countries, some attention should also be given to providing off-seasonal offerings to the conference market as a package.

There are numerous feasible alternatives for a short haul market such as Australia. Although the tradition has always been to travel in the warmer months, a weaker New Zealand dollar and big tax cuts in Australia, coupled with intensive marketing by Tourism New Zealand, could entice Australians to take additional holidays in New Zealand, especially during the off-peak seasons. This is precisely the intention of the "What's On" campaign, which has been launched on the east coast of Australia, to encourage Australians to take short and frequent breaks in New Zealand (Ansley 2006).

The research undertaken in this paper has helped to understand the phenomenon of seasonality. Although the use of simple techniques, such as the ratio-to-moving average method, can be helpful in some contexts, they nevertheless conceal complex issues related to seasonality. For this reason, it is advisable to examine stochastic seasonality and seasonal unit roots, which will be undertaken in future research.

\section{Acknowledgements}

The authors are grateful to two referees for helpful comments and suggestions. The first author is grateful to Ronald Mair of Statistics New Zealand for generous assistance in providing the data, and to the Waikato Management School, University of Waikato, New Zealand and the Nanyang Business School, Nanyang Technological University, Singapore for financial and research support. The second author wishes to acknowledge the financial support of the Australian Research Council.

\section{References}

ANSLEY, G. (2006). Serving Up Bite-Sized Chunks of NZ to Our Neighbours. The New Zealand Herald.

BAR-ON, R. R. (1999). The Measurement of Seasonality and its Economic Impacts. Tourism Economics 5(4): 437-458.

BAUM, T. and LUNDTORP, S. (2001). Seasonality in Tourism. Amsterdam. Pergamon.

BEDFORD, R., HO, E. and LIDGARD, J. (2000). International Migration in New Zealand: Context, Components and Policy Issues. Population Studies Centre Discussion Paper No 37. University of Waikato. New Zealand. 
BEDFORD, R., HO, E. and HUGO, G. (2003). Trans-Tasman Migration in Context: Recent Flows of New Zealanders Revisited. People and Place 11(4): 53-62.

BENNETT, A. (2006). Tourism NZ Digs Deep to Lure Visitors. The New Zealand Herald.

BLOCH, H. (1996). Changes in the International Competitiveness of Australian Manufacturing: 1968 to 1989. The Australian Economic Review 29(3): 308-319.

BUTLER, R. W. (2001). Seasonality in Tourism: Issues and Implications. In Baum, T. and Lundtorp, S. (eds) Seasonality in Tourism. Amsterdam. Pergamon: 5-21.

BUTLER, R. and MAO, B. (1997). Seasonality in Tourism: Problems and Measurement. In Murphy, P. E. (ed) Quality Management in Urban Tourism. Chichester. Wiley: 9-23.

CAMPANO, F. and SALVATORE, D. (2006). Income Distribution. New York. Oxford University Press.

DACRUZ, M. (2006). Come over Queenslanders, its So Much Cooler. The New Zealand Herald.

FARE, R., GROSSKOPF, S. and MARGARTIS, D. (2001). Productivity Trends in Australian and New Zealand Manufacturing. The Australian Economic Review 34(2): 125-134.

FERNANDEZ-MORALES, A. (2003). Decomposing Seasonal Concentration. Annals of Tourism Research 30(4): 942-956.

HAMILTON, J. (1988). Trends in Tourism Demand Patterns in New Zealand: International and Domestic. International Journal of Hospitality Management 7(4): 299-320.

HANKE, J. E., WICHERN, D. W. and REITSCH, A. G. (2001). Business Forecasting (Seventh Edition). Upper Saddle River. Prentice Hall.

HAUGH, D. and HAZLEDINE, T. (1999). Oligopoly Behaviour in the Trans-Tasman Air Travel Market: The Case of Kiwi International. New Zealand Economic Papers 33(1): 1-25.

HEMBRY, 0. (2006). Budget 2006: Extra Cash Brings Mixed Response from Tourism Industry. The New Zealand Herald.

LIM, C., GNOTH, J. and TOH, R. S. (2003). The Travel Balance Approach and Contributing Factors to Tourism Rejuvenation in Aus tralia and New Zealand. Journal of Hospitality and Tourism 1: 83-97.

LIM, C. and MCALEER, M. (2001). Monthly Seasonal Variations: Asian Tourism to Australia. Annals of Tourism Research 28(1): 68-82. LUNDTORP, S. (2001). Measuring Tourism Seasonality. In Baum, T. and Lundtorp, S. (eds) Seasonality in Tourism. Amsterdam. Pergamon: 23-50. NADAL, J. R., FONT, A. R. and ROSSELLO, A. S. (2004). The Economic Determinants of Seasonal Patterns. Annals of Tourism Research 31(3): 697-

711.

NEW ZEALAND DEPARTMENT OF STATISTICS (1979-2005). Monthly Tourist Arrivals. Wellington. OPPERMANN, M. (1994). Regional Aspects of Tourism in New Zealand. Regional Studies 28: 155-167.

PEARCE, D. G. (1990). Tourism, the Regions and Restructuring in New Zealand. Journal of Tourism Studies 1: 33-42.

WANHILL, S. (1980). Tackling Seasonality: A Technical Note. Tourism Management 1(4): 243-245.

YACOUMIS, J. (1980). Tackling Seasonality: The Case of Sri-Lanka. Tourism Management 1(2): 84-98. 